\title{
Regional and Monthly Assessment of Extraterrestrial Solar Radiations in Pakistan
}

\author{
Romana Ambreen1, Iftikhar Ahmad1, Xinfa Qiu2, Menjei Li2 \\ ${ }^{1}$ Department of Geography, University of Balochistan, Quetta, Pakistan \\ ${ }^{2}$ Nanjing University of Information Science and Technology, Nanjing, China \\ Email: iftigeog@gmail.com
}

Received 25 January 2015; accepted 20 February 2015; published 25 February 2015

Copyright (C) 2015 by authors and Scientific Research Publishing Inc.

This work is licensed under the Creative Commons Attribution International License (CC BY). http://creativecommons.org/licenses/by/4.0/

(c) (i) Open Access

\begin{abstract}
The monthly extraterrestrial solar radiations (ESR) have been simulated separately for all the months of the year. The subtropical location and distribution of mountains and their height determine the spatial distribution and amount of ESR in Pakistan. The mountains, piedmonts, enclosed valleys and plains show distinct diversity of ESR values. The assessment acknowledged that countries like Pakistan with ever increasing demand of energy receive sufficient amount of ESR that could be linked with solar irradiance where development of solar energy has great potential. The simulation was done with the help of ArcGIS based on distributed modeling.
\end{abstract}

\section{Keywords}

Pakistan, Extraterrestrial Solar Radiation, Monthly, Spatial Distribution, GIS

\section{Introduction}

Pakistan needs to explore and annex chief available sources of energy for agriculture and urbanization. It seems very difficult to measure the slopes and other topographic information in the field manually for a large area where we lack database of solar radiation, hence distributed models could be reasonable tool to map the extraterrestrial solar radiation (ESR) over rugged terrain. The DEM has been used very efficiently for modeling in the GIS platform in climate and hydrological and other sciences [1]-[3]. Distributed solar radiation models proved to be successfully implied in various scientific avenues including environmental studies, meteorology and climatology [4]-[6]. The differences in landforms height, aspect and orientation of slope play key role in the spatial variation of solar radiation at ground [7]. Various studies have addressed the interaction between solar radiation and rugged complex terrain e.g. [8]-[11]. Since 1980s, spatial modeling got tremendous scope in geosciences [12]. The simulation of solar irradiance as well as possible sunshine duration (PSD) over difficult terrains paved 
the way for estimation of ESR over the rugged territories [13] like Pakistan. Hence, such studies not only provide geospatial database but also provide visualization of geographical accessibility to the resources in difficult terrains. To make the solar energy as a future energy source, it is pivotal to have reliable assessment of solar energy required in diversified topography at small scales [14]. In this paper, an effort has been made to assess ESR in Pakistan at monthly scale and local level with the help of distributed model.

\section{Methodology}

The simulated results are mapped based on digital elevation model (DEM) processed in ArcGIS. The DEM data was retrieved from Shuttle Radar Topography Mission (SRTM) [15]. The sun declination angle and slope in rugged terrain are essential factors to determine the amount of ESR on a particular point or grid. The atmospheric attenuation has not been considered. For more, technical detail read [14]. Some high northward slopes are not exposed to sun shining while there are slopes and plains which never hide from solar exposure until the sun sets. Thus, the landscape contributes by direction, height and steepness (angle) of the slope, while latitudinal extent is the factor which explains the angle of incident flux of solar radiation in different 12 months of the year. The response of the plains and slopes is different in case of ESR, particularly at the sun rise and sun set timings. This makes difference in daily and monthly quantity of ESR received over the plains and slopes. The results are based on the simulated model shown in Figure 1, while physical map has been given with the detail of landforms and national territories in Figure 2 for the easy inculcation of results.

The observed ESR in diversified lands are based on the following principles

$$
\begin{aligned}
W_{o} \alpha \beta= & \frac{T}{2 \pi}\left(\frac{1}{2}\right)^{2} I_{o}\left\{u \sin \delta\left[\sum_{i=1}^{m}\left(w_{s s l}-{ }_{w s r l}\right)\right]+v \cos \delta\left[\sum_{i=1}^{m}\left(\sin w_{s s l}-\sin w_{s r l}\right)\right] u \sin \delta\left[\sum_{i=1}^{m}\left(w_{s s l}-{ }_{w s r l}\right)\right]\right. \\
& \left.+v \cos \delta\left[\sum_{i=1}^{m}\left(\sin w_{s s l}-\sin w_{s r l}\right)\right]-w \cos \delta\left[\sum_{i=1}^{m}\left(\sin w_{s s l}-\sin w_{s r l}\right)\right]\right\}
\end{aligned}
$$

where $W_{o} \alpha \beta$ is the daily quantity of ESR on the grid,

$I_{o}$ represents solar constant,

$\delta$ denotes the solar declination angle,

$u, v$ and $w$ representing geographical/topographical factors:

$$
\begin{aligned}
& u=\sin \varphi \cos \alpha-\cos \varphi \sin \alpha \cos \beta \\
& v=\sin \varphi \sin \alpha \cos \beta+\cos \varphi \cos \alpha \\
& w=\sin \alpha \sin \beta
\end{aligned}
$$

$w_{s r l}$ denotes sunrise hour angle,

$w_{\text {ssl }}$ represents sunset hour angle.

\section{Results and Discussion}

The amount of ESR is less in January, gradually increases with shift to February, March, April to May, and touches maximum level in June and July. After July, the decline in ESR starts gradually and reaches up to minimum in December and January.

January: The ESR in southern parts of the country was observed from $726-809 \mathrm{MJ} / \mathrm{m}^{2}$. The areas mostly stretch along the coastal areas of Balochistan and Sindh. Here from moving onward to the interior of the country from south to north, most obvious zones embracing $662-725 \mathrm{MJ} / \mathrm{m}^{2}$ are central Balochistan, Brahui and Kirthar Ranges, northern Sindh and southern Punjab. Most of the Punjab, Sulaiman ranges excluding their small enclosed valleys; Peshawar valley and surrounding acquire $484-661 \mathrm{MJ} / \mathrm{m}^{2}$. Complex situation persists in northern rugged parts of Hindukush, Karakoram Himalayas (HKH). The southern high slopes obtain ESR that varies from $662 \mathrm{MJ} / \mathrm{m}^{2}$ to $1257 \mathrm{MJ} / \mathrm{m}^{2}$ while some slopes show ESR at low level from 0 - $148 \mathrm{MJ} / \mathrm{m}^{2}$.

February: The ESR observed in southern parts are $810-938 \mathrm{MJ} / \mathrm{m}^{2}$ but the rugged parts received less amount because of shadow impact. From here moving to the interior of the country a wide zone of $728-809$ $\mathrm{MJ} / \mathrm{m}^{2}$ mostly embracing central Balochistan, most of Sindh and southern Punjab; but Brahui.

Kirthar and Sulaiman ranges are exceptions. Most of the Punjab, southern slopes of northern Sulaiman ranges, Peshawar valley and surrounding display $662-725 \mathrm{MJ} / \mathrm{m}^{2}$. In HKH, variety of ESR amount has been detected 

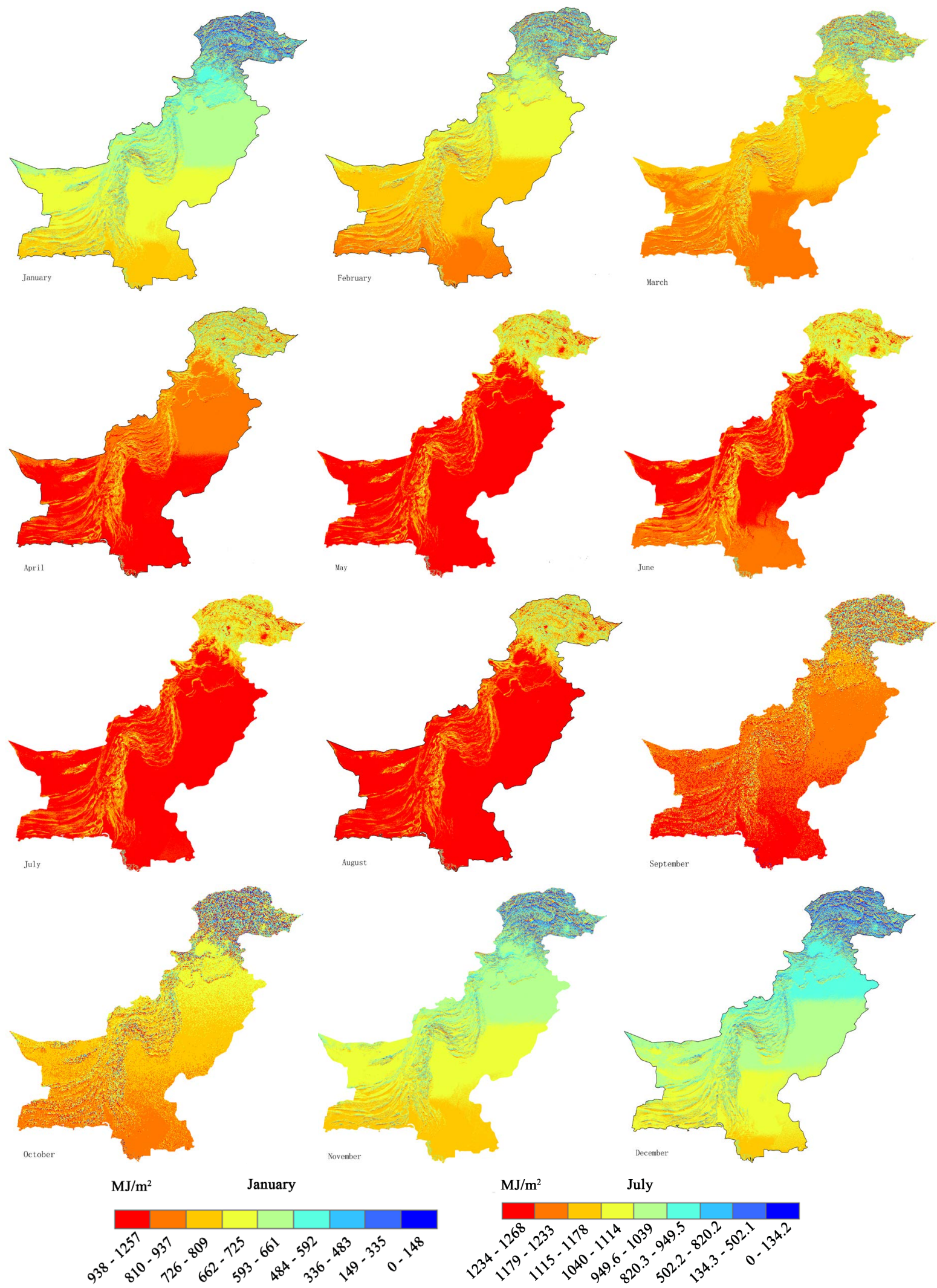

$\mathrm{MJ} / \mathrm{m}^{2}$

July

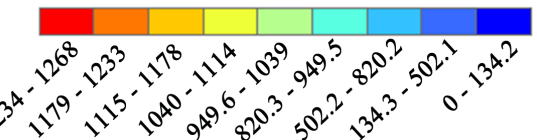

Figure 1. The Figure shows ESR for the twelve months of the year in Pakistan. The keys are shown for the January (minimum ESR) and July (maximum ESR) only, thus the key covers all the other months of the year also. 


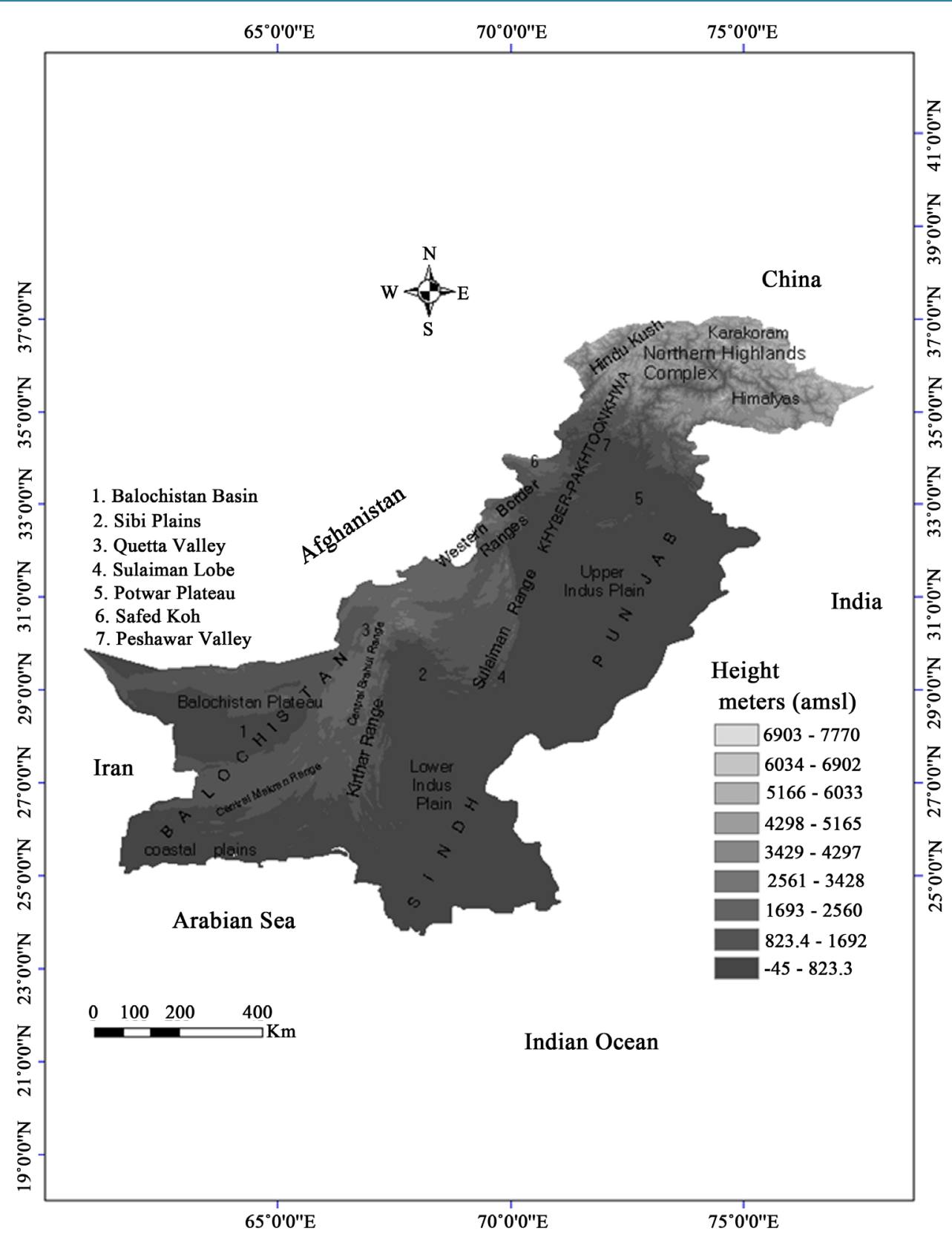

Figure 2. The Figure shows detail of landforms and localities in Pakistan.

due to lofty mountains and their slope aspects, therefore, this area configure 0 to maximum limit of ESR values.

March: Referred to ESR in March southern, central and northern distinct zones of ESR are obvious in the study locus. The southern parts of the country including Balochistan, Sindh with latitudinal extent of about $24^{\circ} \mathrm{N}$ to $29^{\circ} \mathrm{N}$ latitudes, the central zone is extending from about $29^{\circ} \mathrm{N}$ to about $34^{\circ} \mathrm{N}$ latitude embracing the areas of northwestern Balochistan, Punjab (excluding its southern parts), tribal areas, Khyberpakhtoonkhwa (KPK) except its northwestern parts. Northern zone is stretching predominantly over northern rugged parts of the country including HKH Mountains. Hence, southern, central and northern zones are predominantly dominated by 810 $937 \mathrm{MJ} / \mathrm{m}^{2}, 728-809 \mathrm{MJ} / \mathrm{m}^{2}$ and $0-1257 \mathrm{MJ} / \mathrm{m}^{2}$ (about all ranges of ESR) respectively.

April: As the solar declination angle becomes high, the ESR amount is rising in Pakistan and the situation becomes different if compared with winter months. In April, the southern half of Pakistan is obviously dominated by ESR from $938-1257 \mathrm{MJ} / \mathrm{m}^{2}$, at the same time central parts including most of Punjab, KPK and tribal 
areas configure $810-937 \mathrm{MJ} / \mathrm{m}^{2}$. The rugged parts of southern and central Pakistan display variation between $662 \mathrm{MJ} / \mathrm{m}^{2}$ to $1257 \mathrm{MJ} / \mathrm{m}^{2}$. The HKH again has different levels of ESR, the southern slopes received $938 \mathrm{MJ} / \mathrm{m}^{2}$ and above, while the other parts influenced by shadow impact have $338 \mathrm{MJ} / \mathrm{m}^{2}$ and above. Some patches of 810 - $937 \mathrm{MJ} / \mathrm{m}^{2}$ and $262 \mathrm{MJ} / \mathrm{m}^{2}$ and above this limit can also be seen in this part.

May: After April, the major distinct three zones ESR pattern is almost disappeared. Moreover, about all Pakistan is covered by $1234-1268 \mathrm{MJ} / \mathrm{m}^{2}$ except rugged parts. The rugged parts of Balochistan and Sindh mostly have $1115-1178 \mathrm{MJ} / \mathrm{m}^{2}$. During this period in $\mathrm{HKH}$, the patches of $938-1257 \mathrm{MJ} / \mathrm{m}^{2}$ have obviously increased and areas acknowledged by $338-592 \mathrm{MJ} / \mathrm{m}^{2}$ have decreased if compared with April.

June: As the declination angle of the sun in the sky increased consequently possible sunshine duration over Pakistan also increased thus amount of ESR also increased. The northern parts and some valleys were previously in shadow now come under the sunshine in June that increased substantially the amount of ESR in Pakistan. The maximum ESR belt has been shifted further north in the country. From the coastal plains up to Peshawar valley $1234-1288 \mathrm{MJ} / \mathrm{m}^{2}$ prevails but the Brahui, Kirthar Sulaiman ranges have signatures of $1040 \mathrm{MJ} / \mathrm{m}^{2}$ to 1233 $\mathrm{MJ} / \mathrm{m}^{2}$ due to their intershielding impact. The same is true for Safed Koh area in the southwest of Peshawar valley. The HKH region has shown progressive response and the observed amount of ESR was greater than May and July as well.

July: Based on results May, June and July are the months with highest values of ESR acknowledged by 1234 $1288 \mathrm{MJ} / \mathrm{m}^{2}$ in the plains and piedmonts. More or less, we have the same results as in June but the retreat of maximum ESR belt starts in July and onward. All the rugged parts almost indicate a wide range of ESR from $1040 \mathrm{MJ} / \mathrm{m}^{2}$ to $1233 \mathrm{MJ} / \mathrm{m}^{2}$; the same is true for $\mathrm{HKH}$. Nevertheless, $\mathrm{HKH}$ makes little difference originated from the lofty nature of the mountains where southern slopes, northern slopes and valleys create substantial variation in the distribution of ESR that is why almost all the categories of ESR values as shown in the key can be located in $\mathrm{HKH}$.

August: In HKH the screening impact of the mountains are more in August than June and July but at the south of Peshawar valley high values of ESR are still obvious. The plains and open valleys of the country receive 1234 - $1288 \mathrm{MJ} / \mathrm{m}^{2}$. The other ranges like Safed Koh, Sulaiman, Kirthar and Brahui display ESR with values from $1040 \mathrm{MJ} / \mathrm{m}^{2}$ to $1233 \mathrm{MJ} / \mathrm{m}^{2}$.

September: The ESR has been substantially decreased in September as the sun migrates towards the south in the sky with respect to the location of Pakistan. The southern parts of the country receive ESR within the range of $1179-1288 \mathrm{MJ} / \mathrm{m}^{2}$. Mountains have dominant patches of $1040-1178 \mathrm{MJ} / \mathrm{m}^{2}$ while some slopes of high peaks ensure ESR with value of $502.2-1039 \mathrm{MJ} / \mathrm{m}^{2}$, in addition the ESR on piedmonts exhibit 1179 - 1233 $\mathrm{MJ} / \mathrm{m}^{2}$. As we move on northwards, the interior Balochistan exhibits a blend of $1179-1233 \mathrm{MJ} / \mathrm{m}^{2}$ and 1234 $1288 \mathrm{MJ} / \mathrm{m}^{2}$. In Quetta and the surroundings, the plains have 1179 - $1233 \mathrm{MJ} / \mathrm{m}^{2}$ while mountains have 1115 $1178 \mathrm{MJ} / \mathrm{m}^{2}$ on their southern aspects on the contrary the northern slopes have $820.3-1049 \mathrm{MJ} / \mathrm{m}^{2}$. The Indus plains are provided with uniform distribution of $1179-1233 \mathrm{MJ} / \mathrm{m}^{2}$. Further north the Potwar Plateau, Peshawar valley and the surroundings have the ESR ranging from 1115 to $1233 \mathrm{MJ} / \mathrm{m}^{2}$ but the high landforms do not follow and have values from 820.3 to $1039 \mathrm{MJ} / \mathrm{m}^{2}$. The HKH have a variety of values, the southern slopes have 1234 - $1268 \mathrm{MJ} / \mathrm{m}^{2}$, while enclosed valleys have a wide range of ERS comprised of 134.3 to $1178 \mathrm{MJ} / \mathrm{m}^{2}$. The values of $0-134.2 \mathrm{MJ} / \mathrm{m}^{2}$ have been observed on the slopes having less or no exposure to the solar irradiance.

October: The values of $1115-1233 \mathrm{MJ} / \mathrm{m}^{2}$ have been noticed in southern Balochistan and southern Sindh, in this part the rugged territories have $1234-1268 \mathrm{MJ} / \mathrm{m}^{2}, 134.3-945.5 \mathrm{MJ} / \mathrm{m}^{2}$, and $1115-1233 \mathrm{MJ} / \mathrm{m}^{2}$ on southern slopes, northern slopes and piedmonts respectively, furthermore the same is true for the rugged parts of northern Balochistan and northern Sindh. The plains of national central territories possess about 1115 - 1178 $\mathrm{MJ} / \mathrm{m}^{2}$. The values about $1040-1114 \mathrm{MJ} / \mathrm{m}^{2}$ have been identified in the plains of northern Punjab, Potwar Plateau and Peshawar valley. The lofty HKH area demonstrates variability of ESR values including $0-134 \mathrm{MJ} / \mathrm{m}^{2}$; 134 - $502 \mathrm{MJ} / \mathrm{m}^{2} ; 502$ - $820 \mathrm{MJ} / \mathrm{m}^{2} ; 821-1039 \mathrm{MJ} / \mathrm{m}^{2}$ and even small patches of highest ESR values can also be located.

November: The result shows that there is substantial decline of ESR values in the autumn months. Pakistan displays four major distinct zones in November, the southern zone having about $809-1100 \mathrm{MJ} / \mathrm{m}^{2}$, as one proceeds northwards ESR obvious with values of about $662-809 \mathrm{MJ} / \mathrm{m}^{2}$ prevails in most of the Balochistan, northern Sindh and southern Punjab. Mountains remain an exception here with small values. The third zone extends from about $30^{\circ} \mathrm{N}$ latitude up to Peshawar valley where $484-725 \mathrm{MJ} / \mathrm{m}^{2}$ are dominant but the rugged lands remain an exception with 336 - $592 \mathrm{MJ} / \mathrm{m}^{2}$ mostly in Khyber valley and Waziristan Hills however, southern 
aspects remain as exceptions with high values. The HKH represents the fourth zone with least values at the bottom of the slopes and in the valleys but the high southward slopes gain substantial ESR approximately above $810 \mathrm{MJ} / \mathrm{m}^{2}$.

December: If the plains of the national territories are examined, they display a latitudinal pattern starting from $809 \mathrm{MJ} / \mathrm{m}^{2}$ in the south close to $24^{\circ} \mathrm{N}$ latitude, by shift towards north a belt in Balochistan and Sindh shows $662-725 \mathrm{MJ} / \mathrm{m}^{2}$ where Kirthar and Makran ranges stand excluded. Further shift northwards confirms a wide zone of $593-661 \mathrm{MJ} / \mathrm{m}^{2}$ encompasses most of northern Balochistan, northwestern Sindh and southern half of the Punjab, while Brahui and Sulaiman Ranges show lower limit of ESR. The Potwar Plateau, tribal areas and Peshawar valley received $484-592 \mathrm{MJ} / \mathrm{m}^{2}$ in December. The observations in $\mathrm{HKH}$ are the lowest where we have maximum intershielding impact of high mountains but some towering southern slopes still have ESR above $810 \mathrm{MJ} / \mathrm{m}^{2}$.

\section{Conclusion}

The effort is based on the integration of estimated ESR simulated through DEM input into ArcGIS in order to elucidate the patterns and spatial distribution of ESR at monthly scale. The simulated results captured a blended effect of latitude and landforms that show discernible areas of varied ESR per unit area. The plains, mountainous areas, piedmonts and enclosed (open) valleys were found with different responses. In HKH, north of Peshawar valley the situation is quite complex due to towering mountains. The study could be effective for surface regional analysis of solar energy. The HKH nurture Indus River system therefore, the energy balance here based on solar irradiance is of great significance. The spatial distribution of ESR could be instrumental in the estimation of evapotranspiration and solar energy balance for agricultural practices. Based on observations, in ample areas of Pakistan, ESR was above the limit of $1200 \mathrm{MJ} / \mathrm{m}^{2}$ especially in southern parts where we have encouraging prospects of solar energy development. Balochistan and Sindh (southern provinces of Pakistan) could be the best options for generation of electricity from solar energy near to Karachi, the industrial and commercial hub of Pakistan. Additionally, in northern areas, high southern slopes are also appropriate places where solar stations can be established in order to generate electricity.

\section{Acknowledgements}

Authors are thankful to the anonymous reviewers, their comments and suggestions improved the paper substantially.

\section{References}

[1] Dozier, J. and Frew, J. (1990) Rapid Calculation of Terrain Parameters for Radiation Modeling from Digital Elevation Data. IEEE Transaction on Geoscience and Remote Sensing, 28, 963-969. http://dx.doi.org/10.1109/36.58986

[2] Dubayah, R. and Rich, P.M. (1995) Topographic Solar Radiation Models for GIS. International Journal of Geographic Information Systems, 9, 405-413. http://dx.doi.org/10.1080/02693799508902046

[3] Kumar, L., Skidmore, A.K. and Knowles, E. (1997) Modeling Topographic Variation in Solar Radiation in a GIS Environment. International Journal of Geographic Information Science, 11, 475-497. http://dx.doi.org/10.1080/136588197242266

[4] Hetrick, W.A., Rich, P.M. and Weiss, S.B. (1993) Modeling Insolation on Complex Surfaces. Thirteen Annual ESRI User Conference, 2, 447-458.

[5] Rich, P.M., Hetrick, W.A. and Saving, S.C. (1995) Modeling Topographic Influences on Solar Radiation: A Manual for the Solarflux Model. Los Alamos National Laboratory Report LA-12989-M.

[6] Hofierka, J. and Suri, M. (2002) The Solar Radiation Model for Open Source GIS: Implementation and Applications. Proceedings of the Open Source GIS-GRASS Users Conference, Trento, 11-13 September 2002, 19 p.

[7] Fu, P. and Rich, P.M. (2002) A Geometric Solar Radiation Model with Applications in Agriculture and Forestry. Computers and Electronics in Agriculture, 37, 25-35. http://dx.doi.org/10.1016/S0168-1699(02)00115-1

[8] Fu, B.P. (1998) The Differences and Variations in Components of Radiation Budget on Underlying Surfaces of Different Topographies. Chinese Journal of Atmospheric Sciences, 22, 178-190. (In Chinese)

[9] Swift Jr., L.W. (1976) Algorithm for Solar Radiation on Mountain Slopes. Water Resources Research, 12, $108-112$. http://dx.doi.org/10.1029/WR012i001p00108 
[10] Reuter, H.I., Kersebaum, K.C. and Wendroth, O. (2005) Modeling of Solar Radiation Influenced by Topographic Shading-Evaluation and Application for Precision Farming. Physics and Chemistry of the Earth, 30, 143-149. http://dx.doi.org/10.1016/j.pce.2004.08.027

[11] Frank, E.C. and Lee, R. (1966) Potential Solar Beam Irradiation on Slopes: Tables for $30^{\circ}$ to $50^{\circ}$ Latitude. US Forest Service’s Rocky Mountain Forest Range Experimental Station Paper RM-18.

[12] Wan, H.T., Zhou, C.H., Wan, Q., et al. (2001) Integration of Geographical Information System Technology and Hydrological Model. Advances in Water Sciences, 12, 560-568. (In Chinese)

[13] Qiu, X.F., Zeng, Y. and Liu, S.M. (2005) Distributed Modeling of Extraterrestrial Solar Radiation over Rugged Terrain. Chinese Journal of Geophysics, 48, 1100-1107. http://dx.doi.org/10.1002/cjg2.753

[14] Tovar-Pescador, J., Pozo-Vázquez, D., Ruiz-Arias, J.A., Batlles, J., López, G. and Bosch, J.L. (2006) On the Use of the Digital Elevation Model to Estimate the Solar Radiation in Areas of Complex Topography. Meteorological Applications, 13, 279-287. http://dx.doi.org/10.1017/S1350482706002258

[15] Jarvis, A., Reuter, H.I., Nelson, A. and Guevara, E. (2008) Hole-Filled SRTM for the Globe Version 4. Available from the CGIAR-CSI SRTM 90m Database. 
Scientific Research Publishing (SCIRP) is one of the largest Open Access journal publishers. It is currently publishing more than 200 open access, online, peer-reviewed journals covering a wide range of academic disciplines. SCIRP serves the worldwide academic communities and contributes to the progress and application of science with its publication.

Other selected journals from SCIRP are listed as below. Submit your manuscript to us via either submit@scirp.org or Online Submission Portal.
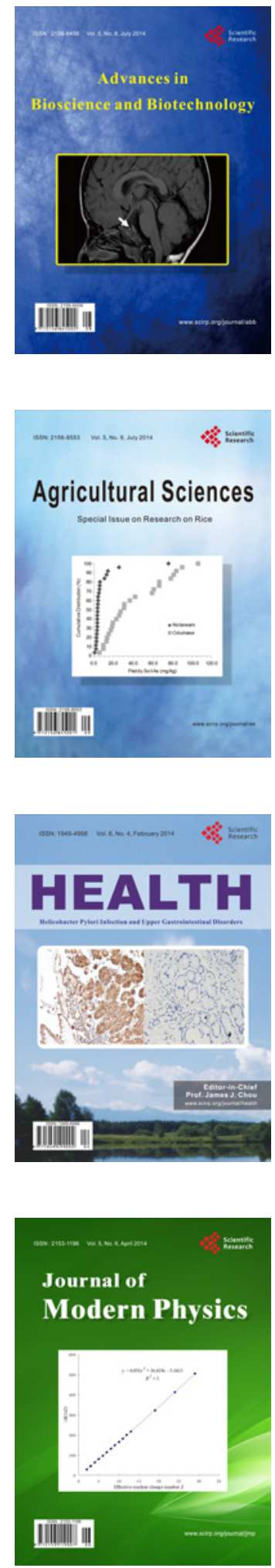
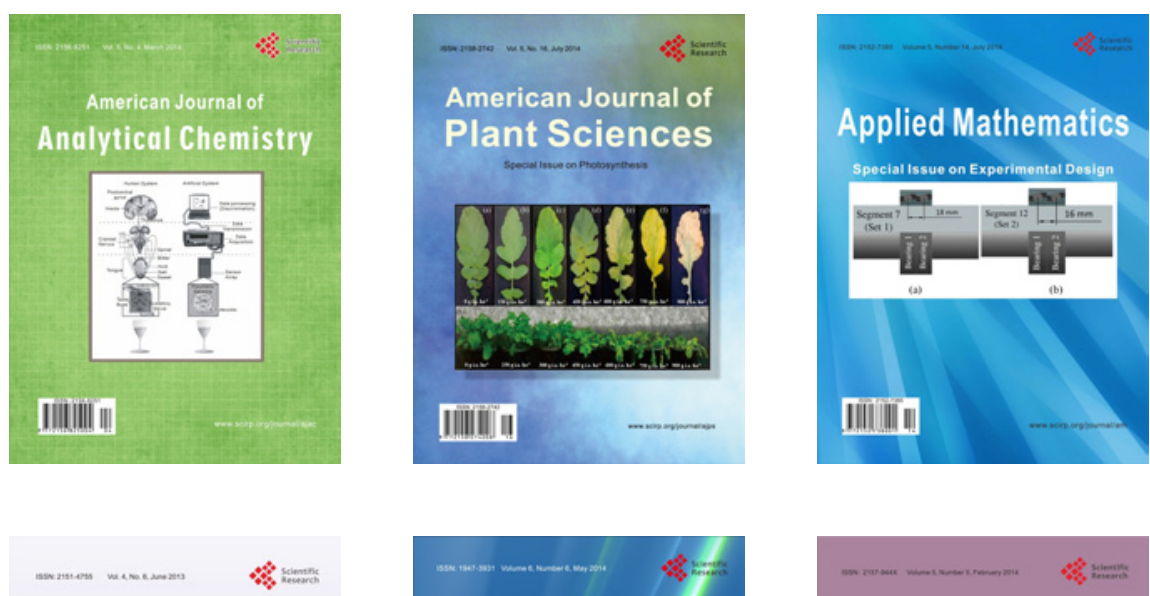

Creative Education
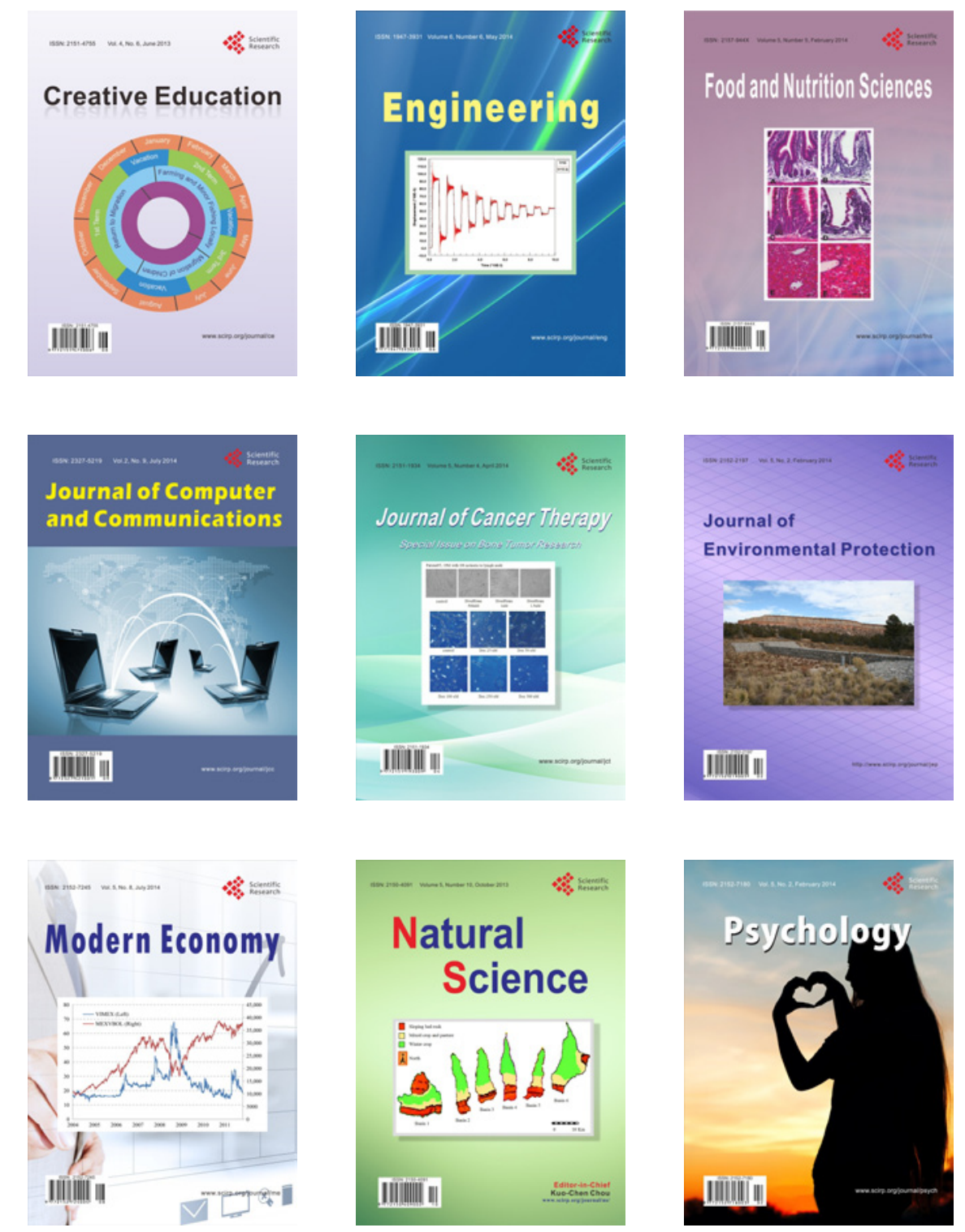